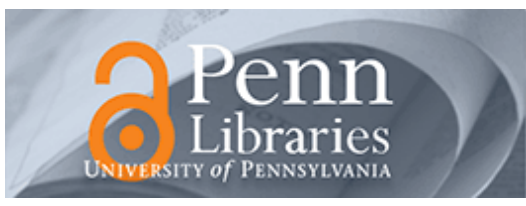

University of Pennsylvania ScholarlyCommons

Wharton Pension Research Council Working

Papers

Wharton Pension Research Council

$1-1-2005$

\title{
Public Pension Governance, Funding, and Performance: A Longitudinal Appraisal
}

Tongxuan (Stella) Yang

The Wharton School, University of Pennsylvania, TONGXUAN@WHARTON.UPENN.EDU

Olivia S. Mitchell

The Wharton School, University of Pennsylvania, mitchelo@wharton.upenn.edu

Follow this and additional works at: https://repository.upenn.edu/prc_papers

Part of the Economics Commons

Yang, Tongxuan (Stella) and Mitchell, Olivia S., "Public Pension Governance, Funding, and Performance: A Longitudinal Appraisal" (2005). Wharton Pension Research Council Working Papers. 376.

https://repository.upenn.edu/prc_papers/376

This paper is posted at ScholarlyCommons. https://repository.upenn.edu/prc_papers/376

For more information, please contact repository@pobox.upenn.edu. 


\title{
Public Pension Governance, Funding, and Performance: A Longitudinal Appraisal
}

\begin{abstract}
Pension plans covering US public sector employees now face the twin challenges of poor asset returns and rapid increases in liabilities, producing the worst pension funding outcomes in decades. This paper explores how public pension plan investment performance and funding is related to several structural and pension design features. Using a new longitudinal dataset on state and local public pension plans, we evaluate how investment performance is tied to stock funding ratios and how stock funding ratio in turn affects flow funding efforts. We find that particular governance structures can enhance public pension plan investment performance and funding status, and we suggest ways in which public plan design might be improved.
\end{abstract}

\section{Disciplines}

Economics 


\title{
Public Pension Governance, Funding, and Performance: A Longitudinal Appraisal
}

\author{
Tongxuan (Stella) Yang and Olivia S. Mitchell
}

\section{PRC WP 2005-2}

\author{
Pension Research Council Working Paper \\ Pension Research Council \\ The Wharton School, University of Pennsylvania \\ 3620 Locust Walk, 3000 SH-DH \\ Philadelphia, PA 19104-6302 \\ Tel: 215.898.7620 Fax: 215.898.0310 \\ Email:prc@wharton.upenn.edu \\ http://prc.wharton.upenn.edu/prc/prc.html
}

\begin{abstract}
Yang is a doctoral candidate and Bradley Fellow at the Wharton School, University of Pennsylvania. Mitchell is the International Foundation of Employee Benefit Plans Professor of Insurance and Risk Management; Executive Director of the Pension Research Council; and Director of the Boettner Center for Pensions and Retirement Research, all at the Wharton School of the University of Pennsylvania. Funding for this research was provided by the Pension Research Council, the Boettner Center, and a Bradley Foundation Fellowship (Yang). Without implicating them, we acknowledge helpful assistance and suggestions Chris Allen, Nick Greifer, Robert Inman, Karl Johnson, Marie-Eve Lachance, Steven Nesbitt, John Piggott, and Perry Young. Opinions and any errors remain the authors' responsibility. (C) Yang and Mitchell, 2004. All Rights Reserved.
\end{abstract}

This paper is to be published in Shortchanged? Pension Fund Governance and Retirement Provision. Ed. John Piggott. Edward Elgar. Forthcoming 2005.

Pension Research Council Working Papers are intended to make research findings available to other researchers in preliminary form, to encourage discussion and suggestions for revision before final publication. (C2005 Pension Research Council of the Wharton School of the University of Pennsylvania. All Rights Reserved. 


\title{
Public Pension Governance, Funding, and Performance: A Longitudinal Appraisal
}

\author{
Tongxuan (Stella) Yang and Olivia S. Mitchell
}

\begin{abstract}
$\underline{\text { Abstract }}$
Pension plans covering US public sector employees now face the twin challenges of poor asset returns and rapid increases in liabilities, producing the worst pension funding outcomes in decades. This paper explores how public pension plan investment performance and funding is related to several structural and pension design features. Using a new longitudinal dataset on state and local public pension plans, we evaluate how investment performance is tied to stock funding ratios and how stock funding ratio in turn affects flow funding efforts. We find that particular governance structures can enhance public pension plan investment performance and funding status, and we suggest ways in which public plan design might be improved.
\end{abstract}

Tongxuan (Stella) Yang (corresponding author)

Dept of Insurance \& Risk Management, Wharton School, University of Pennsylvania 3620 Locust Walk, St. 3000 SH-DH,

Philadelphia, PA 19104-6302

T: 215-898-3589

E-mail: tongxuan@wharton.upenn.edu

\section{Olivia S. Mitchell}

International Foundation of Employee Benefit Plans Professor

Dept. of Insurance \& Risk Management, Wharton School

3620 Locust Walk, St. 3000 SH-DH

Philadelphia, PA 19104-6302

T: 215-898-0424

E-mail: mitchelo@wharton.upenn.edu 


\title{
Public Pension Governance, Funding, and Performance: A Longitudinal Appraisal
}

\author{
Tongxuan (Stella) Yang and Olivia S. Mitchell
}

Public pension plans are the mainstay of retirement security for millions of public sector employees plans around the world. In the US, these plans have traditionally been of the defined benefit (DB) variety, holding around $\$ 3$ trillion in assets (Ilkiw, 2003) and covering a range of state and local civil servants, teachers and university professors, uniformed workers (firefighters, police). Though these pensions play a key role in US labor and capital markets, analysts and taxpayers have devoted relatively little attention to them until recently, when serious funding problems emerged due to assets standing well below levels needed to cover promised benefits. Recently, over two-thirds of all state pension systems were judged to be underfunded (Nesbitt 2003), and additional concerns are emerging as equity market declines, paired with low interest rates, have attracted media interest. ${ }^{1} \mathrm{~A}$ wide variety of stakeholders stands to lose if public pension funding ratios sink, including retirees who might suffer benefit cuts, and taxpayers who may have to pay for underfinanced benefit claims. ${ }^{2}$ Such pension liabilities can also reduce governments' ability to attract and retain high-quality employees, ${ }^{3}$ and underfunding can also influence credit ratings, potentially increasing risk premia for public debt. ${ }^{4}$

Traditionally, public pension plans have differed from their corporate counterparts in the US because state and local pensions are not subject to national regulation shaping their funding targets, how they must be managed, what they can invest in, and how they report their performance. Rather, each state and many localities structure their Boards according to local rules, they set investment and performance targets independently within each jurisdiction, and they manage their pensions according to local practice. For this reason, there is a rich variety of 
experience with alternative governance and reporting structures in the public plan arena that can be used to assess the determinants of successful public plan funding. In this paper we employ a newly constructed longitudinal dataset on state and local pensions to evaluate how funding status responds to governance structures and investment strategies. In what follows, we use the longitudinal PENDAT file to describe public pension funding patterns over the last decade, along with a discussion of investment performance. Next, we construct an empirical model to explore the determinants of public pension investment performance and funding. Our results point out which governance and disclosure factors are of key interest to policymakers and stakeholders seeking to make public plans more resilient in the international arena.

\section{An Overview of Public Plan Funding Patterns and Investment Performance}

Public pension plans in the US have been surveyed approximately biennially by the Public Pension Coordinating Council (PPCC) in the last decade. The resulting datafiles, known as the "PENDAT surveys," capture a wide range of public retirement system practices regarding plan administration, membership, benefits, contributions, funding, and investments. ${ }^{5} \mathrm{We}$ summarize key information gleaned from these surveys in Table 1, which indicates the number of state and local plans reporting over time, as well as their asset holdings and liabilities.

\section{Table 1 here}

The data show, for instance, that state and local plans surveyed held a median $\$ 1.7$ billion in assets in 2000, with reported liabilities of around the same magnitude. The distribution is quite skewed, so mean plan assets and liabilities in the sample are on the order of $\$ 10$ billion. Following convention, we define the stock funding ratio as the ratio of assets to the present value of vested funded liabilities: that measure stood at approximately 100 percent in 2000 . This factor 
is indicative of whether a pension plan's assets are sufficient to collateralize promised benefits in the long run (Mitchell and Smith, 1994). ${ }^{6}$ By contrast, the flow funding measure captures the ratio of "required" to actual annual contributions in a given year; the evidence shows that these plans did meet their annual contribution with a ratio of just over 100 percent.

Table 1 also shows that reported public pension assets and liabilities grew over time, and assets rose more quickly than liabilities. This produced enhanced funding ratios over the decade of 1990's. For instance, stock funding stood at only 86 percent and flow funding at around 89 percent in 1990, but both measures had risen to around 100 percent by 2000. Since averages conceal substantial diversity, stock funding ratios ranged from 0 to 500 percent in our sample. ${ }^{7}$ The top panel of Table 1 also indicates that contributions fell slightly over the period, in response to good investment performance. The lower panel indicates public plan investment performance over the last decade. During the decade, managers obtained positive real single year returns in all years but one. On the other hand, one-year returns were quite volatile, reaching a high of 13.5 percent in 1998 and a low of -0.6 percent in 1994; furthermore, cross-sectional standard deviations reached 7.8 percent in 1991. Naturally, the five-year average returns are smoother, ranging from 5.2 to 11.3 percent, with correspondingly smaller volatility. In what follows, we turn to an examination of funding over time and across plans, and we explore how these are linked to investment returns and governance factors.

\section{Prior Public Pension Research}

Most early studies on public pensions have been of a descriptive and cross-sectional nature, so most did not evaluate specific explanations for why some public plans may have outperformed others. ${ }^{8}$ A few analytic works did investigate the determinants of public plan 
funding outcomes using a single equation cross-section approach, while a smaller set still have developed a multi-equation approach to control for possible endogeneity. For our purposes, the outcomes of particular interest in that body of literature are pension funding measures and investment returns; control variables include attributes of the plans including governance features, mainly board composition, management practices, and reporting practices; and pension investment practices, relating to whether the plan had restrictions on specific investment categories. We summarize these studies in Table $2 .{ }^{9}$

\section{Table 2 here}

As is clear, most previous studies used single-equation models to relate outcomes of interest to control variables. For instance, Inman (1985) linked teacher pension funding patterns to environmental variables; he concluded that underfunding was worse in older, more industrialized cities, and in poorer rural states. The study by Hsin and Mitchell (1994) also used cross-sectional data to evaluate the determinants of public pension plan funding including fiscal stress and governance variables; that paper concluded that actuarial assumptions (specifically, assumptions about interest rates, wage growth rates, and amortization periods) appeared to be set strategically to meet changing fiscal situations. A subsequent analysis (Mitchell and Hsin, 1997) also employed cross-sectional data to link both funding and investment performance outcomes to governance variables including board composition. That study found that funding was enhanced by having in-house actuaries and when pension Board members were required to carry liability insurance. Funding was lower when states experienced fiscal stress, and when employees were represented on the pension system Board.

In another single-equation regression study, Mark (1997) employed panel data for 19721991 to explore funding practices across states and over time. That analysis concluded that 
underfunding was a mean-reverting process, rather than a random walk. He also reported that stock market returns and fiscal budget surpluses had positive effects on funding, and more frequent actuarial studies caused underfunding to revert more quickly to equilibrium. However he did not investigate the role of governance factors, nor did Chaney et al. (2002) who used 1994-95 data in a single-equation study to revisit the relationship between underfunding and fiscal stress as well as state balanced budget restrictions. The latter paper concluded that public plan funding was worse when states experienced fiscal stress and when states had mandatory balanced budget requirements. Coronado et al. (2003) explored whether conflicts of interests inherent in public pension plans hurt plan investment performance. Employing cross-section PENDAT 2000 data, those authors found some evidence that economically targeted investments and country/industry restrictions were associated with lower investment returns, and that public plans earned a significantly lower rate of return than did private plans.

Only three prior studies have used multiple-equation models to evaluate public plan funding and investment behavior, allowing for the possibility that plan funding may be endogenously determined with other plan characteristics. One report, by Inman (1982), was not concerned with funding per se; rather, the author investigated whether public pension funding affected public employee earnings and labor supply, and also whether taxpayers might flee a locality to avoid being taxed to cover unfunded public pension liabilities. Data from 60 large U.S. police and firefighter plans for 1970-73 were used to estimate a three-equation model determining public employee wages, employment levels, and pensions. That analysis concluded that higher wages could offset pension underfunding, and that taxpayer migration might occur to avoid public plan underfunding. A later analysis (Johnson 1997) explored the question of why pension plans in the public sector are more generous than in the private sector, using a two- 
equation recursive model. The author showed that the relative generosity of a public pension plan was related to the ability to underfund the plan, which in turn was constrained by outmigration. The third previous multi-equation study, by Mitchell and Smith (1994), analyzed interactions between required pension contributions, actual contributions, and public sector wage levels. That research used cross-sectional data from the late 1980s to show that pension funding practices tend to be perpetuated over time, and that underfunding grows in times of fiscal pressure.

To summarize, then, the majority of prior public pension studies did not focus mainly on funding and investment performance. Those that did tended to confirm, using single-equation models, that public plan funding and investment performance were influenced by governance and investment practice factors. Nevertheless, prior studies did not take into account the possibility that plan funding and investment performance may be endogenously determined, and that funding results in one year may be related to lagged funding measures. In what follows, we explore both possibilities using a new panel data set from PENDAT.

\section{Methodology}

We build on previous research on public plans in two ways. First, our focus is on public plan funding and investment performance, using a decade of data on US public pension plans. Except for Mitchell and Smith (1994), ${ }^{10}$ prior authors have not examined the extent to which funding status persists over time for public plans and what leads to this outcome. In the present study, therefore, we investigate in more detail the links between past and current funding ratios. Second, our particular interest is in examining the links between plan funding and governance structure, taking into account investment performance. Our panel data set offers an insight into 
behavior through time, enriching findings from the predominately cross-sectional studies in the literature.

The econometric model posits that three dependent variables are of most interest: a plan's stock funding ratio, its flow funding ratio, and its investment performance. To understand how funding outcomes in public pension plans are developed via the actuarial evaluation process, Figure 1 describes the key relationships between dependent variables. At time t, usually in midyear, a public pension plan asks in-house or outside actuaries to conduct an actuarial evaluation on plan assets and liabilities. From these data, both the stock funding ratio in year $\mathrm{t}$ and the required contribution for year $\mathrm{t}+1$ are calculated. Then, between time $\mathrm{t}$ and $\mathrm{t}+1$, the plan sponsor must make contributions according to its policy. At the end of year $\mathrm{t}+1$, the flow funding ratio of that year can be calculated from the actual and required contributions.

Figure 1 here

The relationships we posit among the three dependent variables of most interest may be clarified with the help of Figure 2. StockFund ${ }_{t}$ FlowFund $_{t+l}$ and $\mathrm{ROR}_{t}$ are the dependent variables representing, respectively, the plan's stock funding ratio, flow funding ratio, and investment performance. The specific empirical framework we estimate with the PENDAT information may therefore be stipulated as follows:

$$
\begin{aligned}
& \text { StockFund }_{t}=\alpha_{0}+\alpha_{1} \text { ROR }_{t}+\alpha_{2} \text { StockFund }_{t-1}+\alpha_{3} \text { Composition }_{t} \\
& +\alpha_{4} \text { Management }_{t}+\alpha_{5} \text { Reporting }_{t}+\alpha_{6} X_{t}+e_{1} \\
& +\beta_{5} \text { Reporting }_{t}+\beta_{6} X_{t}+e_{2} \\
& +\gamma_{4} \text { Reporting }_{t}+\gamma_{5} \text { Investment }_{t}+\gamma_{6} X_{t}+e_{3}
\end{aligned}
$$


Figure 2 here

Here, investment returns are hypothesized to have a positive effect on stock funding, and that, in turn, stock funding affects flow funding. We also hypothesize that the dependent variables are influenced by three types of factors: lagged dependent variables, factors representing plan governance, and indicators of plan investment practices. Specifically, Composition,

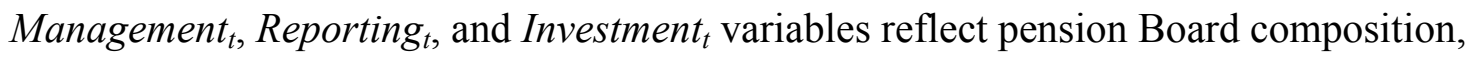
management practice, reporting practice, and investment practice; and the $X_{t}$ vector refers to other control variables.

Pension liability measures used here involve the Actuarial Accrued Liability (AAL) concept, which differs from other liability measures used in past public pension studies. ${ }^{11}$ Of course, the choice of the discount rate used in computing liabilities plays an important role in funding models. ${ }^{12}$ In the PENDAT, the nominal discount rates reported range from 4.5 to 11.2 percent, with the real discount rate from -0.22 to 7.67 percent. We follow Chaney et al. (2002) to adjust liabilities to a common economic discount rate. ${ }^{13}$ Again, required contributions are adjusted using the same approach.

Since we postulate that the stock funding ratio can affect future flow funding ratios, the model is recursive and it may be estimated using pooled OLS with robust standard errors. ${ }^{14}$ In what follows, we first discuss the dependent variables and their lags, as well as the relationships between each other. Then we turn to a discussion of the remainder of the findings.

\section{Endogenous Dependent Variables}

The stock funding ratio, as noted above, represents the ratio of plan assets to liabilities. It reflects the accumulated effects of plan contributions plus investment performance on plan assets, and it also reflects changes in plan liabilities. In the corporate sector, federal regulations 
require that plan sponsors maintain full funding and boost contributions if levels go low. By contrast in the public sector, no such regulation is nationally mandated. As a result, public plans may have less incentive to fully fund, and in most cases unfunded pension liabilities can be amortized over future years. Hence we hypothesize that the stock funding ratio in year $t$ will be positively correlated with a plan's past stock funding ratio, which we capture through the use of a lagged dependent variable.

In addition, when modeling stock funding patterns, we must recognize that investment returns can also influence plan funding levels. For example, state and local governments have historically tended to prohibit managers from investing in what were perceived to be "risky" assets, including equity, venture capital, and foreign holdings. In the early 1990s, for instance, public plans were still found to hold more conservative assets than private plans, and hence they earned returns below those of market indices (Mitchell and Hsin, 1997). Over the 1990s, however, the PENDAT file reveals that public plans gradually increased their equity holdings (from around 35 percent in 1990 to 55 percent in 2000). Naturally, holding more equities means the plan is subject to more volatile investment returns, so public pension plan funding levels are more sensitive to investment returns today than they were decades ago. Nevertheless, previous studies on public sector pension plan funding have stressed the willingness and capacity of state and local governments to make enough contributions, while neglecting the more and more important role played by plan investment performance (Epple and Schipper 1981, Mitchell and Smith 1994, Copley et al. 2002). In what follows, the empirical model allows investment returns to be determinative of pension funding status, and the expectation is that this relationship is positive. 
The second dependent variable of interest is the flow funding ratio, which reflects how well a plan meets its annual contribution requirements, as determined by plan actuaries. A positive link between flow and stock funding would be anticipated if a government jurisdiction has a persistent political climate or "culture"; thus one might expect "behavioral persistence" with respect to funding, which would indicate a positive and possibly unitary relationship between actual and stock funding measures. An alternative hypothesis would be that state and local governments would seek to balance actual and required contributions, but they might not necessarily do so over a period as short as one year. In this case, the long-term relationship between stock and flow funding would reflect "mean reversion;" that is, a period of flow underfunding would be followed by one of overfunding. One prior study sought to differentiate between these hypotheses using cross sectional 1989 data for 42 plans, and it concluded behavioral persistence dominates; i.e. that there is a positive relationship between stock and flow funding ratio (Mitchell and Smith, 1994). We also test the hypothesis using our larger and longitudinal dataset.

The third dependent variable of interest is the plan's investment performance, measured here by rates of return reported on pension investments. Clearly high investment returns are preferred, other things equal, since they enable the plan to maintain funding while avoiding extra contributions. In addition, we also are aware that past funding behavior might affect a pension plan's investment strategy. For one thing, a well-funded pension plan may be more able to bear investment risk than a poorly funded plan, since the stronger plan has more of a buffer to withstand a bear market. From this logic, one might expect a positive link between the plan's lagged funding ratio and its current investment return. Alternatively, an underfunded pension might invest in riskier portfolios, in the hopes of improving its asset base. In this latter case, we 
would expect lagged stock funding to be inversely related to current investment returns. Below we will explore which prediction is supported empirically.

\section{Explanatory Variables}

Because public plans are responsible for so many participants and such a large pool of investment funds, analysts have recently become interested in how such pensions are governed. Governance refers to "the systems and processes by which a company or government manages its affairs with the objective of maximizing the welfare of and resolving the conflicts of interest among its stakeholders" (Carmichael and Palacios, 2003). In practice, state and local retirement systems are run by a retirement Board that has authority over investments, actuarial valuations, system operations, and often plan benefits as well. Day-to-day administration is usually managed by the retirement system's staff (Mitchell et al. 2000). In the US, public plans exhibit great diversity in their governance structures: some funds include active participants, while others have only appointed Board members; some plans have annual reporting requirements, while others do not; and some are subject to statutory investment restrictions, while others have more freedom. In our empirical models, we measure plan governance along three dimensions: Board composition, management practices, and reporting practices.

Board composition practices are proxied by the percentage of employees on public pension Boards, which prior analysts have suggested may reduce stock funding and investment performance (Mitchell and Hsin, 1997). Here we disaggregate further to ask whether having active versus retired members has a differential impact. Most likely, plan participants will be more concerned with their benefits and push for better funding, than would politically affiliated members such as appointed and ex-officio representatives. On the other hand, Mitchell (1988) suggests that Board members who are not financially expert may find it difficult to monitor plan 
performance, in which case having more active or retired members may permit lower funding. Which effect dominates is an empirical matter to be explored. The composition of the pension Board may also influence investment performance. Previously studies have found mixed results on this point, with no statistically significant impact discerned in cross sectional data by Useem and Mitchell (2000), but a negative impact of retiree Board members on returns in Mitchell and Hsin (1997). We hypothesize that having more participants on the Board may lead to lower returns due to a more conservative approach to investments. ${ }^{15}$

To evaluate plan management practices in public pensions, we control on expense ratios, defined as the sum of administrative and investment cost over total plan assets; these would be expected to have a negative impact on stock funding. Some 43 percent of plans in the sample also have reciprocal agreements with other retirement systems, permitting transfers or service credits earned elsewhere. Such portability would be anticipated to have a negative influence on public plan stock funding, as indicated by Mitchell and Hsin (1997). Another factor distinguishing plans is where the funds come from to cover contributions; for a quarter of our sample, states or cities have dedicated special taxes to cover plan contributions. It is possible that this approach enhances funding, since the plan enjoys a stable income source rather than being influenced by variable state or local government revenues. In this case, having a special tax may be positively tied to better funding. On the other hand, a state or local government might fail to fill contribution gaps if it depends on a dedicated income stream to meet contribution requirements. Our analysis investigates the links between special taxes and plan funding ratios empirically. Additionally, in many public pension plans the Board of Trustees influences actuarial assumptions used in setting plan funding levels. One key factor is the amortization period for past service liabilities: having a longer amortization period reduces the level of 
required contributions, thus making it easier for employers to meet annual contribution requirements. We hypothesize a positive link between the assumed amortization period and flow funding levels.

States and localities have developed alternative approaches to solving the principal-agent problem arising from the fact that the plan's Board of Trustees acts as the agent for the principals, who are taxpayers and plan participants. One concern mentioned by Hess and Impavido (2003) is that trustees might act in their own self-interest or may simply shirk their duties. Another is that public sector trustees may seek to use fund assets to further the social or political goals of the party in power. Clearly it is critical to effectively and efficiently monitor plan Trustees, which is likely to be facilitated if annual reports are provided containing financial, actuarial, statistical, and investment information. For this reason we hypothesize that annual reporting practices should positively influence both funding ratios and investment performance. We also find it useful to control the practice for whether trustees are covered by liability insurance, since private insurers may monitor plan investment behavior in lieu of effective oversight and reporting. Nevertheless, we acknowledge that having liability insurance might increase moral hazard if trustees feel they can invest less prudently when covered. Which effect dominates empirically is explored below.

Plan reporting practices can be very important to pension plan investment outcomes. This is evident, in some cases, where plans engage independent entities to evaluate pension investment performance. The argument is that, when well done, independent performance evaluation can improve plan investment performance by introducing best-practice management techniques. Additionally, outside evaluation can boost information flows to taxpayers and plan participants, enabling them to better monitor Board behavior. While independent performance 
evaluations are expected to enhance pension investment returns, previous literature has provided little hard evidence supporting the supposition: Mitchell and Hsin (1997), as well as Useem and Mitchell (2000) did not find a link between performance reviews and pension plan investment returns. We revisited these findings using our decade-long sample of pension plan performance and structure.

We also take note that plan investment practices can play a critical role in influencing pension plan outcomes. Except liability insurance mentioned above, another aspect of investment practices is an indicator of socially-targeted investments. These refer to investments where social development targets are included as well as risks and returns. Such targeted investments can reduce plan investment performance, if the level of portfolio diversification decreases. Prior studies reported a negative link between investment directed in-state and one-year investment returns (Mitchell and Hsin 1997) though others argue that such policies do not hurt investment performance (Munnell and Sunden 2001). A recent study on this topic, Coronado et al. (2003), found some evidence that in-state investment and country/industry restrictions have a negative influence on public sector plan investment performance, although these results are relatively weak. In our study, we hypothesize that the higher the fraction of plan assets which are directed in-state, the lower will be the plan's investment returns. Due to the fact that markets rose substantially over the 1990s, the regressions also control both stock market performance (proxied by S\&P 500 returns), and plan asset allocation (proxied by proportions of assets invested in stocks and international assets), to accurately measure how plan governance influences on investment performance.

In addition to the plan structure variables described above, we also control on several other factors recommended by prior studies. For instance, facing budget shortfalls can produce 
fiscal distress, which translates into lower pension plan contributions. ${ }^{16}$ Three studies have proxied fiscal distress by the deviation between a state's recent unemployment rate and its longterm average (Mitchell and Smith 1994, Mitchell and Hsin 1997 and Johnson 1997); prior results show that above-average unemployment is associated with lower public pension funding. Using a different measure of stress, Chaney et al. (2002) found that state budget deficits reduced pension funding outcomes. Below, we predict that fiscal distress negatively affect funding ratios. This may be aggravated when a state has a balanced-budget requirement, as per Mitchell and Hsin (1997) and Chaney et al. (2002). That is, the funding status of state pension plans might be inversely related to the existence of a balanced budget requirement because such requirement tends to enhance borrowing from trust funds, like pension funds, according to the GAO (1985). In what follows, we control on whether states have a balanced budget requirement or whether they can carry over imbalances. Finally, our multivariate analysis controls on pension plan size, on the grounds that scale economies are important in public pension system (Mitchell and Andrews, 1981).

\section{Empirical Results}

Most of the variables we use are drawn directly from the PENDAT survey files which reported public retirement system and plan practices regarding administration, membership, benefits, contributions, funding, and investments. In addition, three variables are derived from outside sources, namely indicators of fiscal stress, budget carry-over practice, and stock market returns. As an indicator of fiscal stress we use "Unempd," which is the deviation of the local unemployment rate from the long-term average. We use "Nocarry" as an indicator that the state 
is permitted to carry over a budget deficit from one year to the next. We also control on the aggregate S\&P 500 level, to proxy for market-wide stock market performance. ${ }^{17}$

Table 3 presents our main empirical results, pooling data on all available plans over the period 1990-2000. ${ }^{18}$ Equation (1) focuses on the stock funding ratio, where we see that higher investment returns are positively related to stock funding outcomes. Specifically, if investment returns rise by 1 percentage point, stock funding rises by 0.42 percentage points. This positive and large association explains why public plan funding in the 1990s was so strong, but it also helps understand why public plan funding rates declined when the market turned down in 2000 .

\section{Table 3 here}

We also find that stock funding patterns are positively correlated over time, confirming the behavioral persistence hypothesis. This is partly due to the fact that there is no uniform public plan funding regulation, as there is for private pension plans under ERISA. Nevertheless, stock funding ratios across years are not perfectly correlated, so that one-percentage point higher stock funding in one year is associated with 0.76 percentage point greater funding the following year. In other words, on average, public plans do make an effort to fill in an underfunding gap over time, though not fully from one year to the next.

Governance variables such as Board composition are also found to play an important role in determining plan funding status. The results suggest that, other things equal, having more participants on the Board, either retired or active plan members, is associated with lower levels of public plan stock funding. The coefficients are strong and negative: the point estimates indicate that adding 1 more active plan member on Board decreases stock funding by 0.7 percentage point, and 1 more retired member will decrease stock funding ratio by 1.7 percentage points. These findings are consistent with the magnitudes reported by Mitchell and Hsin (1997). 
Management practices are also influential: having a dedicated tax for contributions appears to reduce, rather than enhance, funding. This may be because state or local governments may assume that such taxes cover needed contributions so that they do not fill the gap when one arises. This contrasts with Mitchell and Hsin (1997) who found that funding did not respond to having a dedicated tax; however their data were cross-sectional and did not control on lagged dependent variables. We find no evidence in Table 3 that fiscal distress due to unusually high unemployment rates prompts public employers to underfund their pension promises. This result is consistent with the study of Mark (1997) who also finds no direct link, but contrasts with Mitchell and Hsin (1997), Johnson (1997) and Chaney et al. (2002), who do report a negative link between government fiscal distress and pension underfunding. Further, the data reveal no significant effect of having budget non-carryover requirements for stock funding, consistent with Bohn and Inman (1996) and Mitchell and Hsin (1997). Our results do contrast with Chaney et al. (2002), whose research is cross-sectional and does not control on the endogenous effect of investment performance and governance practice as we have.

Equation (2) explores the determinants of flow funding, where we see a positive association between current flow funding and past stock funding patterns. Nevertheless, this relationship is not one to one; when stock funding ratio increases one percentage point, the flow funding ratio rises by only about half a percentage point. Hence, the "behavioral persistence" hypothesis cannot be rejected consistent with Mitchell and Hsin (1997), and the point estimates suggest that persistence is attenuated by "mean reversion" effects. Since there is no additional tie between investment performance and flow funding, we conclude that flow funding responds to stock funding, rather than current investment performance. It is interesting that having more retirees on the Board is associated with lower flow funding patterns, but having active 
participants is not statistically significant. Once again, having a special tax dedicated to contributions reduces flow funding, as was true for stock funding. While many of the other control variables are not statistically significant (fiscal stress, plan size, and budget carry-over policy), we do find that plans reporting a longer amortization period are more likely to report higher flow funding, consistent with our earlier discussion.

Equation (3) focuses on the determinants of investment performance. Here we see that the lagged funding ratio is not statistically significant, holding constant portfolio mix and other factors. On the other hand, the composition of the pension Board does have an effect on pension investment performance: specifically, yields are significantly lower when retiree representation increases, which confirms findings in Mitchell and Hsin (1997). This could be due to the lack of expertise of retired participants in investment decision-making. We also find that pension reporting practices have a potent effect on investment returns. For instance, having an annual report is positively and significantly associated with investment returns, and the effect is large: annual returns are almost 2.1 percentage points higher for plans providing annual reports containing financial, actuarial, statistical, and investment information. This may be due to the mitigation of information asymmetry, which helps stakeholders monitor trustees more effectively.

Our study also confirms that some pension investment practices are influential in plan performance. There is a negative link between economically targeted investments (when assets must be directed in-state) and plan investment returns but the effect is not statistically significantly different from zero, consistent with a recent study by Munnell and Sunden (2001), but in contrast to earlier analysis by Mitchell and Hsin (1997). Greater concentration of the portfolio in stocks (or international equity) had a positive (negative) association with pension 
investment returns, holding constant market performance (proxied by S\&P 500 returns). A one percentage point rise in the S\&P 500 was associated with higher public sector pension annual investment returns of 0.42 percentage points.

Table 4 summarizes our main empirical results, focusing only on statistically significant and interesting relationships in the context of current economic conditions. All estimates hold other factors constant at their mean values. One provocative finding is that a 30-percent drop in the S\&P 500 index, such as was experienced during 2000-2002, would be predicted to cut public pension investment returns by 12 percentage points. Given that the real annual return over the prior decade averaged less than 8 percentage points, this is a substantial impact. A large drop in investment returns would also depress stock funding: a 20 percentage point change in one-year returns would cut the stock funding ratio by 8 percentage points. Turning to the stock funding ratio, Nesbitt (2003) reported a 24 percentage point drop between 2000 and 2002; according to our model, this would decrease the flow funding ratio by 11 percentage points. Governance changes could also have an important effect: for example, adding one more active plan member to a Board would be predicted to lower a plan's stock funding ratio by 0.7 percentage points. Adding a retired member would decrease the stock funding ratio by 1.7 percentage points, drop flow funding by 2.3 percentage points, and cut annual investment returns by 0.4 percentage points. Finally, holding all else equal, issuing an annual report with financial, actuarial, statistical, and investment information would boost a plan's annual investment returns by 2.1 percentage points. ${ }^{19}$

Table 4 here

\section{Discussion and Conclusions}


Prior studies on public pension plan performance did not take into account the possibility that pension funding and investment performance may be endogenously determined, and that funding patterns may be linked over time. This paper explores both possibilities, and also it examines the links between plan funding and governance structure, taking into account investment performance. Our longitudinal data set offers a view of behavior across years, enriching findings from what have been mainly cross-sectional analyses in prior literature.

The results suggest that investment performance positively influences stock funding ratios in public sector pension plans, and stock funding ratios in turn positively affect flow funding ratios. In addition, plan funding status tends to be positively correlated over time, confirming that there is behavioral persistence in pension manager behavior. Supportive of previous research, we find that public plan governance has an important impact on plan investment performance and funding status. Having more retired employees on the Board can depress investment performance, stock funding, and flow funding, while having more active employee participation can depress stock funding. Regarding management and investment practices, we confirm that having a special dedicated tax does not enhance funding. Investment practices also have an important impact on plan investment performance, as does plan transparency. When a plan reports its financial, actuarial, statistical and investment information, that plan is more likely to have higher investment returns.

Our research is particularly timely in view of the fact that global capital markets are experiencing some of the strongest shocks of the last half-century. The S\&P 500 index dropped by around 30 percent between 2000 and 2002; our estimates suggest that a 30 percent drop in the S\&P 500 index would be predicted to depress public plan investment returns by 12 percentage points, while a 20 percentage point drop in plan investment return would depress stock funding 
ratios by 8 percentage points. To make public plans more resilient to such shocks, plan governance structure could be enhanced to boost investment performance and funding status. One way would be to include more expert Board members; another might be to provide better training to Board representatives, especially if they are active or retired employees.

There is reason to believe that these findings are also relevant for pension plans in the corporate pension sector. For instance, corporate accounting standards have come under heavy scrutiny of late (Fore, forthcoming), partly as a result of extraordinary drops in private-sector DB plan underfunding driven by some of the same phenomena as in the public sector. In fact, the abrupt global downturn in DB plan funding levels is raising questions regarding whether pension plan reporting and transparency in all sectors should be required to conform to new and more comprehensive international standards. Indeed, recent experience with public pensions does suggest that greater transparency could enhance both funding and investment results. Pension stakeholders of all stripes would be expected to benefit from more detailed and timely financial, actuarial, statistical, and investment information. What the costs of such additional transparency might be is a topic for future research. 


\section{References}

Bahl, R., and B. Jump, Jr. (1974) “The Budgetary Implications of Rising Employee Retirement System Costs", National Tax Journal, Sept. 1974: 479-490.

Berman, Judy. (2003) “Pension-fund Deficits Tax Many Cities: Cocoa Faces \$795,852 Shortfall”, Florida Today, June 19, 2003,.

Bohn, Henning and Robert P. Inman. (1996) "Balanced-Budget Rules and Public Deficits: Evidence from the U.S. States", Carnegie-Rochester Conference Series on Public Policy, 45: $13-76$.

Carmichael, Jeffrey and Robert Palacios. (2003), “A Framework for Public Pension Fund Management", Paper presented at the Conference on Public Pension Fund Management, World Bank, Washington DC.

Chaney, Barbara A., Paul A. Copley, and Mary S. Stone. (2002) “The Effect of Fiscal Stress and Balanced Requirements on the Funding and Measurement of State Pension Obligations”, Journal of Accounting and Public Policy, 21: 287-313.

Chernoff, Joel. (2003) “California Exploring Different Ways to Fund Retirement Systems”, Pension \& Investments. January 20.

Coronado, Julia L., Eric M. Engen and Brian Knight. (2003), "Public Funds and Private Capital Markets: The Investment Practices and Performance of State and Local Pension Funds”, National Tax Journal, Vol. LVI, No. 3, 579-594.

D’Arcy, Stephen P., James H. Dulebohn, and Pyungsuk Oh. (1999) “Optimal Funding of State Employee Pension Systems”, Journal of Risk and Insurance, Vol. 6, Issue 3: 345-380. 
Dulebohn, H. James. (1995) “A Longitudinal and Comparative Analysis of the Funded Status of State and Local Public Pension Plans”, Public Budgeting \& Finance, Summer: 52-72.

Epple, Dennis and Katherine Schipper. (1981). "Municipal Pension Funding: A Theory and Some Evidence", Public Choice, Vol. 37: 141-178.

Fore, Douglas. (forthcoming) “Changes in Accounting Practice Will Drive Pension Paradigm Shifts." In Re-inventing the Retirement Paradigm. Eds. Olivia Mitchell and Robert Clark. Oxford University Press.

Government Finance Officers' Association. (GFOA). (2000). "Survey of State and Local Government Employee Retirement Systems: Survey Report.” GFOA Research Center, April.

Hess, David and Gregorio Impavido. (2003), “Lessons From Corporate Governance And International Evidence.” Paper presented at the Conference on Public Pension Fund Management, World Bank, Washington DC.

Hsin, Ping-lung and Olivia S. Mitchell. (1994) “The Political Economy of Public Pensions: Pension Funding, Governance, and Fiscal Stress", Revista de Analisis Economico, Vol. 9, No. 1: 151-168.

Inman, Robert P. (1985) “Appraising the Funding Status of Teacher Pensions: An Econometric Approach", National Tax Journal, Vol 39, No. 1: 21-34. 
Inman, Robert P. (1982) "Public Employee Pensions and the Local Labor Budget", Journal of Public Economics, 19: 49-71.

Ilkiw, John. (2003) “Investment Policies, Processes and Problems in U.S. Public Sector Pension Plans: Some Observations and Solutions from a Practitioner.” Paper presented at the Conference on Public Pension Fund Management, World Bank, Washington DC.

Johnson, Richard W. (1997) "Pension Underfunding and Liberal Retirement Benefits Among State and Local Government Workers", National Tax Journal, March 1997; Vol. 50, No. $1,113-139$.

Mark, Stephen T. (1997) “The Welfare Implications of Political and Economic Decentralization”. Unpublished Ph.D Dissertation. Wharton School, University of Pennsylvania.

Mitchell, Olivia S. (1988) "Worker Knowledge of Pension Provisions", Journal of Labor Economics 6: 21-39. and Emily Andrews. (1981) "Scale Economies in Private Multi-Employer Pension Systems." Industrial and Labor Relations Review 34 (July): 522-530. and Ping-Lung Hsin. (1997) "Public Sector Pension Governance and Performance”, The Economic of Pensions: Principles, Policies and International Experience, Salvador Valdes Prieto, ed. Cambridge: Cambridge Univ. Press: 92-126. , David McCarthy, Stanley C. Wisniewski, and Paul Zorn. (2000). "Developments in State \& Local Pension Plans." In Pensions for the Public Sector. Eds. O.S. Mitchell \& E. Hustead. Philadelphia, PA: Univ. of Pennsylvania Press: 11-40. 
and Robert S. Smith. (1994) "Pension Funding in the Public Sector", Review of Economics and Statistics, May, Vol.76, No.5: 278-290.

Mumy, Gene. (1978) “The Economics of Local Government Pensions and Pension Funding”, The Journal of Political Economy, Vol 86, Issue 3: 517-527.

Munnell, Alicia H., and Annika Sunden. (2001) “Investment Practices of State and Local Pension Funds: Implications for Social Security", In Pensions in the Public Sector, Olivia S. Mitchell and Edwin C. Hustead, ed., Philadelphia, University of Pennsylvania Press: 153-194.

Nesbit, Stephen L. (2003) 2003 Wilshire Report on State Retirement System: Funding Levels and Asset Allocation. Wilshire Associates, Inc., March.

Scannell, Kara. (2002) “Public Pension Plans Come Up Short”, Wall Street Journal, August 16.

Smalhout, James H. (2003) "Pension Bonds a Risky Cop-Out: Borrowing to Fund Retirement Plan Sets a Dangerous Precedent”, Los Angeles Times, June 29.

Public Pension Coordinating Council. (2002) "2001 Survey of State and Local Government Employee Retirement Systems: Survey Report”, March.

Taylor, S. S. (1986) Public Employee Retirement Systems: The Structure and Politics of Teacher Pensions. Ithaca, NY: ILR Press.

Testin, Blair. (1984) Comparative Survey of Major Public Pension Plans, State of Wisconsin Retirement Research Committee Staff Report \#74, Madison, WI: Retirement Research Committee. 
(1986) Comparative Survey of Major Public Pension Plans, State of Wisconsin

Retirement Research Committee Staff Report \#77. Madison, WI: Retirement Research Committee.

, and R. K. Snell. (1989). Comparative Statistics of Major State Retirement Systems,

1984-1988, National Conference of State Legislatures, Fiscal Affairs Program Legislative

Finance Paper \#68, May.

Turner, John, and Dan Beller. (1989) Trends in Pensions 1989. Washington, D.C., USGPO: 443446.

United States General Accounting Office (1993). Balanced Budget Requirements: State Experiences and Implications for the Federal Government. US Government Printing Office, Washington DC.

United States General Accounting Office (1985) Budget Issues: State Balanced Budget Practices. US Government Printing Office, Washington DC.

Useem, Michael and Olivia S. Mitchell. (2000) "Holders of the Purse Strings: Governance and Performance of Public Retirement System.” Social Science Quarterly, Vol 81, 2: 491506.

Warsmith, Stephanie. (2003) “Ohio Teacher Benefits Cut: Loss of Subsidized Health Care for Retirees Means New or Increased Premiums in 2004”, Beacon Journal, May 16. http://www.ohio.com/mld/ohio/living/education/6061408.htm

Winkelvoss, Howard. (1993) Pension Mathematics with Numerical Illustrations, 2e. Philadelphia: University of Pennsylvania Press. 
Wooldridge, Jeffrey M. (2002) Econometric Analysis of Cross Section and Panel Data.

Cambridge, MA: MIT Pres.

Young, Perry. (2003) "Public Pension Funds Under Stress.” Comments at Public Pensions in Uncertain Times Seminar, Standard \& Poor's, New York, May. 
Table 1. US Public Plan Assets, Liabilities, Funding, Contribution Patterns, and Investment Performance

A. Public Plan Assets, Liabilities, Funding, and Contribution Patterns (in 2000 dollars)

\begin{tabular}{lcccccccc}
\hline & & 1990 & 1991 & 1992 & 1994 & 1996 & 1998 & 2000 \\
\hline Assets (\$M) & & & & & & & \\
& Mean & 1,847 & 1,759 & 2,559 & 3,336 & 3,836 & 5,938 & 10,300 \\
Liabilities (\$M) & & & & & & & \\
& Mean & 2,420 & 2,186 & 3,202 & 3,946 & 4,398 & 6,176 & 10,000 \\
& Median & 344 & 164 & 450 & 682 & 557 & 761 & 1,691 \\
Stock Funding Ratio (\%) & & & & & & & \\
Mean & 86.45 & 89.85 & 89.58 & 87.42 & 89.02 & 94.00 & 98.63 \\
Std.dev. & 50.44 & 48.42 & 44.76 & 34.34 & 22.78 & 22.17 & 22.64 \\
Flow Funding Ratio (\%) & & & & & & & \\
Mean & 89.50 & 99.97 & 95.02 & 97.88 & 97.59 & 99.63 & 101.42 \\
Std.dev. & 32.99 & 45.36 & 32.40 & 18.34 & 11.05 & 27.56 & 28.22 \\
Contribution Rate (\%) & & & & & & & \\
& Mean & 12.88 & 13.49 & 13.63 & 13.93 & 12.78 & 11.96 & 11.84 \\
Std.dev. & 9.69 & 9.58 & 10.44 & 10.04 & 9.88 & 8.27 & 10.08 \\
\hline
\end{tabular}

B. Investment Performance: Real Returns

\begin{tabular}{lcccccccc}
\hline \multicolumn{1}{l}{} & & 1990 & 1991 & 1992 & 1994 & 1996 & 1998 & 2000 \\
\hline 1-yr Return (\%) & & & & & & & & \\
& Mean & 2.81 & 11.02 & 5.75 & -0.59 & 10.79 & 13.53 & 2.44 \\
\multicolumn{1}{l}{ Av. 5-yr Return (\%) } & Std.dev. & 4.60 & 7.76 & 3.08 & 3.89 & 3.74 & 4.52 & 5.97 \\
& & & & & & & & \\
& Mean & 7.77 & 6.54 & 6.84 & 5.23 & 8.40 & 11.28 & 10.71 \\
& Std.dev. & 2.53 & 1.76 & 1.64 & 1.17 & 1.85 & 2.31 & 2.42 \\
\hline Sample size & & 124 & 203 & 144 & 174 & 228 & 190 & 125 \\
\hline
\end{tabular}

Source: Authors' computations using PENDAT 1990-2000; see text. 
Table 2. Prior Research on Public Plan Funding: Summary of Empirical Findings

\begin{tabular}{|c|c|c|c|}
\hline & StockFund & FlowFund & ROR \\
\hline \multicolumn{4}{|l|}{ Endogenous variables: } \\
\hline StockFund & & $\begin{array}{l}\text { >0 Sig: Mitchell/Smith } \\
\text { (1994) }\end{array}$ & \\
\hline \multicolumn{4}{|l|}{ FlowFund } \\
\hline \multicolumn{4}{|l|}{ ROR } \\
\hline \multicolumn{4}{|l|}{ Explanatory variables: } \\
\hline \multicolumn{4}{|l|}{ 1. Governance } \\
\hline \multicolumn{4}{|l|}{ Board Composition } \\
\hline$\%$ Active Members & $<0$ Sig: Mitchell/Hsin (1997) ${ }^{1}$ & NS: Mitchell/Hsin (1997) & $\begin{array}{l}\text { NS: Useem/ Mitchell (2000); } \\
\text { Mitchell/Hsin (1997) } \\
\text { Coronado et.al. (2003) }\end{array}$ \\
\hline$\%$ Retired Members & <0 Sig: Mitchell /Hsin (1997) & NS: Mitchell/Hsin (1997) & $\begin{array}{l}<0 \text { Sig: Mitchell/Hsin (1997) } \\
\text { NS: Useem/Mitchell (2000) }\end{array}$ \\
\hline \multicolumn{4}{|l|}{ Management Practices } \\
\hline SpecTax & NS: Mitchell/Hsin (1997) & NS: Mitchell/Hsin (1997) & \\
\hline Portable & $<0$ Sig: Mitchell/Hsin (1997) & & \\
\hline AmortPerc & & NS: Mitchell/Hsin (1997) & \\
\hline \multicolumn{4}{|l|}{ Reporting Practices } \\
\hline Disclose & NS: Mitchell/Hsin (1997) & NS: Mitchell/Hsin (1997) & \\
\hline IndPerf & & & $\begin{array}{c}\text { NS: Useem/Mitchell (2000) } \\
\text { Mitchell/Hsin (1997) }\end{array}$ \\
\hline \multicolumn{4}{|l|}{$\begin{array}{l}\text { 2. Pension Investment } \\
\text { Practice }\end{array}$} \\
\hline InState & & & $\begin{array}{l}<0 \text { Sig: Mitchell/Hsin (1997); } \\
\text { NS: Munnell/Sunden (2001); } \\
\text { Coronado et.al. (2003) }\end{array}$ \\
\hline InvstIns & $>0 ;$ Mitchell/Hsin (1997) & & \\
\hline \multicolumn{4}{|l|}{ 3. Other Controls } \\
\hline Fiscal stress & $\begin{array}{c}\text { <0 Sig: Mitchell/Hsin (1997); } \\
\text { Chaney et al. }(2002)^{2} \\
\text { Johnson (1997) } \\
\text { NS: Mark (1997) }\end{array}$ & NS: Mitchell/Hsin (1997) & \\
\hline NoCarry & $\begin{array}{c}\text { <0 Sig: Chaney et al. (2002) } \\
\text { NS: Mitchell/Hsin (1997); } \\
\text { Bohn/Inman (1996) }\end{array}$ & $\begin{array}{l}\text { NS: Bohn/Inman (1996); } \\
\text { Mitchell/Hsin (1997). } \\
\text { <0 Sig: Mitchell/Smith } \\
\text { (1994) }\end{array}$ & \\
\hline S\&P500 & $>0$ Sig: Mark (1997) & & \\
\hline
\end{tabular}

See Appendix for variable definitions. NS means not significant. Sig means significant at least at 10 percent level. Notes:

1. Mitchell/Hsin (1997) uses proportion of Board member elected by active and retired members, while we use proportion of Board members who themselves are active or retired plan participants. Useem/Mitchell (2000) and Coronado et.al. (2003) uses total Board members elected by members.

2. Chaney et al. (2002) use the current year general fund surplus measure as the fiscal distress.

3. Mark's (1997) funding measure uses plan unfunded liabilities divided by plan income rather than a more conventional stock or flow funding measure.

4. Bohn and Inman (1996) summarize unreported regression results in text. 
Table 3. Determinants of Public Pension Plan Funding Status and Investment Performance: Pooled OLS with robust standard errors

(std. errors in parens; hypothesized signs at the left of column results)

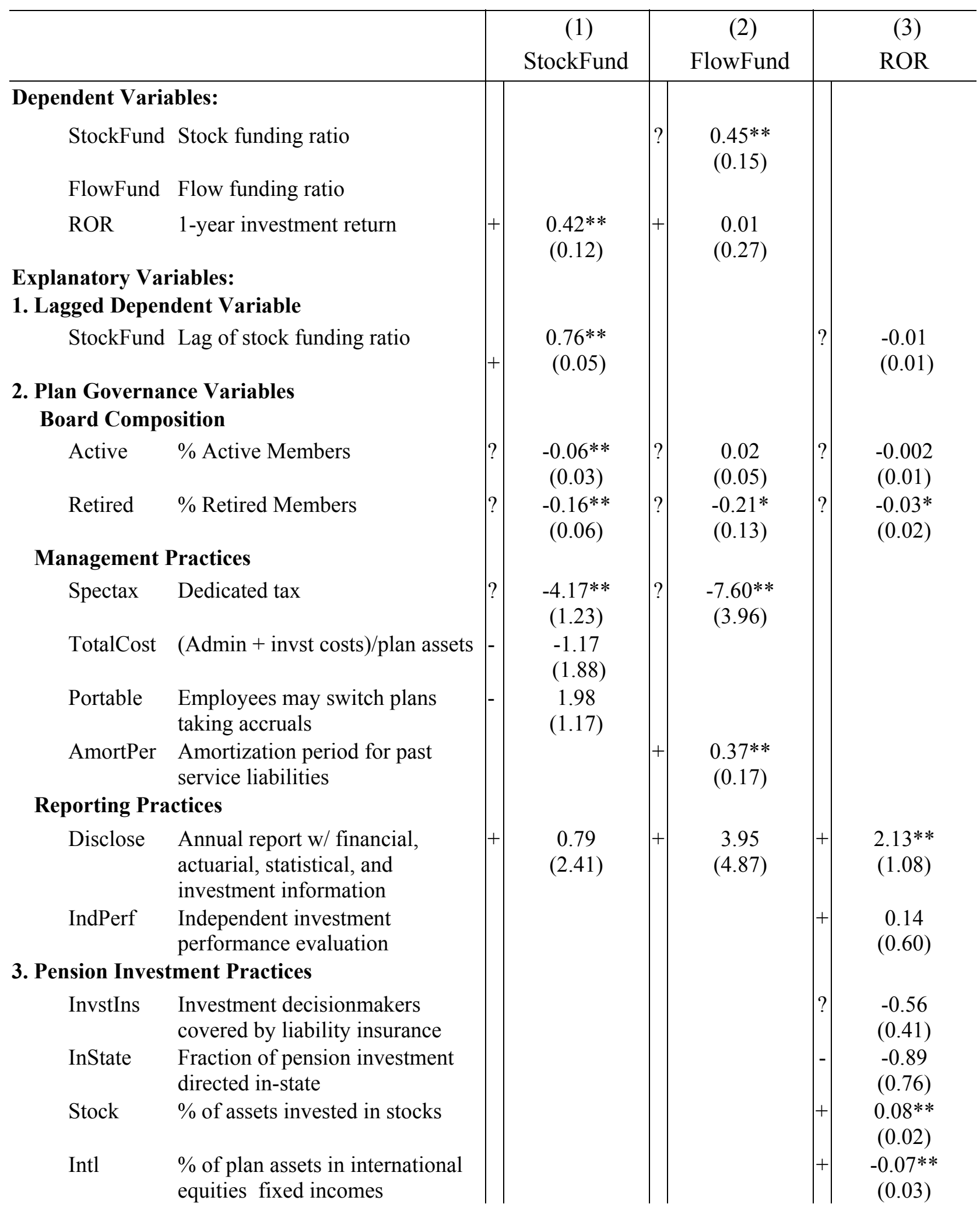


Table 3 (cont)

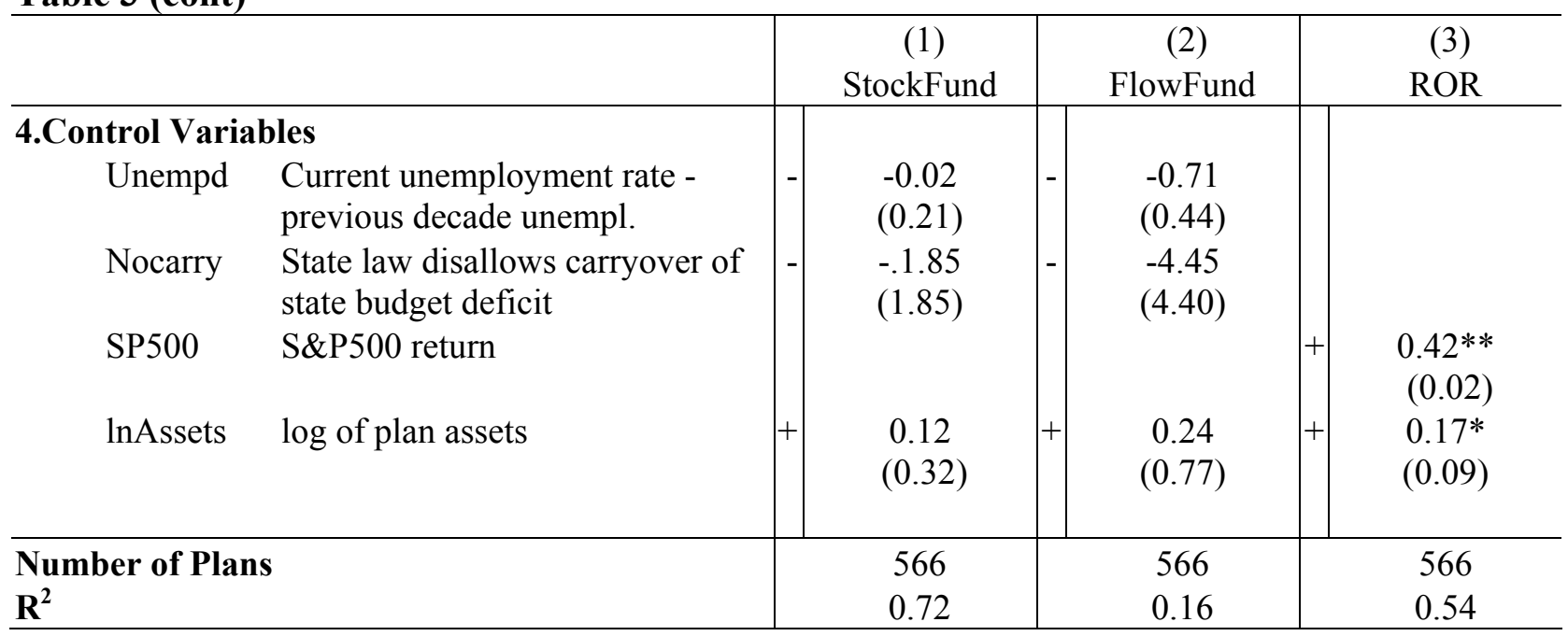

Note: $\quad * *$ Significant at $5 \%$ level

* Significant at $10 \%$ level

See Appendix for variable definitions.

Source: Authors' computations using the PENDAT 1990-2000; see text. 
Table 4. Estimated Responsiveness of Key Explanatory Variables

\begin{tabular}{|c|c|c|c|}
\hline & $\begin{array}{c}\text { Stock Funding } \\
\text { Ratio }\end{array}$ & $\begin{array}{c}\text { Flow Funding } \\
\text { Ratio }\end{array}$ & $\begin{array}{c}\text { 1-yr Investment } \\
\text { Return }\end{array}$ \\
\hline \multicolumn{4}{|l|}{$\begin{array}{l}\text { Capital Market \& Performance } \\
\text { Factors: }\end{array}$} \\
\hline-30 percentage pt in $\mathrm{S} \& \mathrm{P} 500$ index & & & -12 percentage pts \\
\hline $\begin{array}{l}-20 \text { percentage pt in } 1-y r \text { plan } \\
\text { investment return }\end{array}$ & -8 percentage pts & & \\
\hline$-24 \%$ in plan stock funding ratio & & -11 percentage pts & \\
\hline \multicolumn{4}{|l|}{ Governance Factors } \\
\hline+1 active Board member & -0.7 percentage pts & & \\
\hline+1 retired Board member & -1.7 percentage pts & -2.3 percentage pts & -0.4 percentage pts \\
\hline Annual report issued & & & +2.1 percentage pts \\
\hline
\end{tabular}

See Appendix for variable definitions.

Source: Authors' computations using the PENDAT 1990-2000; see text. 
Figure 1: The Actuarial Evaluation Process in Public Pension Plans

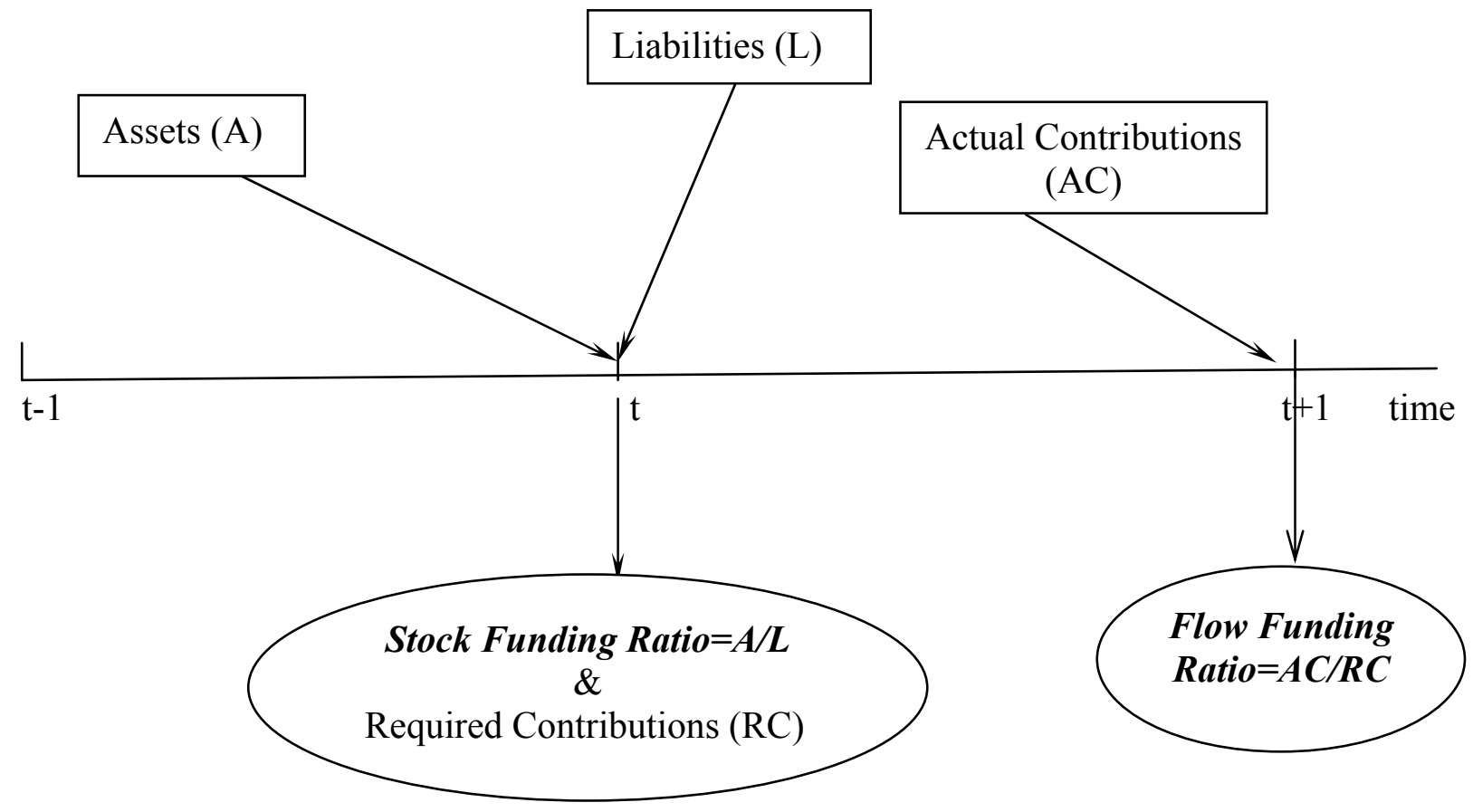

Figure 2: Hypothesized Relationship between Public Plan Investment Performance, Stock Funding, and Flow Funding

\begin{tabular}{|c|c|c|}
\hline $\begin{array}{l}\text { Investment } \\
\text { performance }\end{array}$ & $\begin{array}{l}\text { Stock Funding } \\
\text { Ratio }\end{array}$ & Flow Funding \\
\hline
\end{tabular}




\section{Appendix: Descriptive Statistics and Variable Definitions}

\begin{tabular}{|c|c|c|c|}
\hline & & Mean & Standard Deviation \\
\hline \multicolumn{4}{|c|}{ Dependent Variables: } \\
\hline StockFund & Stock funding ratio $(\%)$ & 88.07 & 26.42 \\
\hline FlowFund & Flow funding ratio $(\%)$ & 97.96 & 31.69 \\
\hline ROR & Annual investment return (\%) & 7.90 & 6.93 \\
\hline \multicolumn{4}{|c|}{ Explanatory Variables: } \\
\hline \multicolumn{4}{|c|}{ 1. Lags } \\
\hline StockFund & Lag of stock funding ratio (\%) & 84.77 & 29.09 \\
\hline \multicolumn{4}{|c|}{ 2. Governance Structure } \\
\hline \multicolumn{4}{|c|}{ Pension Board Composition } \\
\hline Active & $\%$ Active Members & 51.92 & 24.08 \\
\hline Retired & $\%$ Retired Members & 11.49 & 11.54 \\
\hline \multicolumn{4}{|c|}{ Management Practice } \\
\hline Spectax & Dedicated tax $(0 / 1)$ & 0.25 & 0.43 \\
\hline TotalCost & (Admin+invest. costs) / plan assets (\%) & 0.48 & 0.61 \\
\hline Portable & EEs may switch plans taking accruals $(0 / 1)$ & 0.44 & 0.50 \\
\hline AmortPer & $\begin{array}{l}\text { Amortization period for past service } \\
\text { liabilities (number) }\end{array}$ & 22.19 & 12.64 \\
\hline \multicolumn{4}{|c|}{ Pension Reporting Practice } \\
\hline Disclose & $\begin{array}{l}\text { Annual report w/ financial, actuarial, } \\
\text { statistical, and investment information (0/1) }\end{array}$ & 0.96 & 0.20 \\
\hline IndPerf & $\begin{array}{l}\text { Independent investment performance } \\
\text { evaluation }(0 / 1)\end{array}$ & 0.86 & 0.35 \\
\hline \multicolumn{4}{|c|}{ 3. Pension Investment Practice } \\
\hline InvstIns & $\begin{array}{l}\text { Investment decision makers covered by } \\
\text { liability insurance }(0 / 1)\end{array}$ & 0.49 & 0.50 \\
\hline InState & $\%$ of pension investment directed in-state & & \\
\hline & & 0.08 & 0.27 \\
\hline Stock & $\%$ of assets invested in stocks & 49.75 & 14.96 \\
\hline Intl & $\begin{array}{l}\% \text { of assets invested in international equities } \\
\text { and bonds }\end{array}$ & 8.21 & 8.25 \\
\hline \multicolumn{4}{|c|}{ 4.Control Variables } \\
\hline Unempd & $\begin{array}{l}\text { Current unemployment rate - av. past } \\
\text { decade unemployment rate (\%) }\end{array}$ & 1.14 & 2.80 \\
\hline Nocarry & $\begin{array}{l}\text { State law disallows carryover of state } \\
\text { budget deficit }(0 / 1)\end{array}$ & 0.77 & 0.42 \\
\hline SP500 & S\&P500 return $(\%)$ & 14.57 & 11.71 \\
\hline lnAssets & Natural log of plan assets $(\$)$ & 12.98 & 2.40 \\
\hline
\end{tabular}

Number of Observations: 566

See Appendix for variable definitions.

Source: Authors' computations using the PENDAT 1990-2000; see text. 


\section{Endnotes}

${ }^{1}$ See, for instance, Scannell (2002), Smalhout (2003), Chernoff (2003) and Berman (2003).

${ }^{2}$ For example, Ohio's public school teachers and administrators plan (STRS) required retired teachers with fewer than 15 years of teaching to pay their full health care premiums. In addition, retiree groups were unable to salvage subsidies that had traditionally been provided for teacher's spouses and dependents (Warsmith 2003).

${ }^{3}$ Past research has shown that public employees require compensating wage differentials in times of more severe underfunding, which in turn drives salary pressure (Mitchell and Smith, 1994: Inman, 1982).

${ }^{4}$ Young (2002) notes that inadequately funded pension plans can drag down sponsor credit quality.

5 The PENDAT file is quite reflective of the national public plan universe, representing approximately 58 percent of all public retirement plans, 67 percent of active plan participants and 68 percent of all state and local retirement system assets in fiscal year 2000 (PPCC, 2002). Data available in machine-readable format cover years 1990, 1991, 1992, 1994, 1996, 1998, and 2000.

${ }^{6}$ GASB Statement No. 27 requires public pension plans to report Actuarial Accrued Liabilities (AAL), with a cost method selected from a menu (e.g. Entry Age Normal, Projected Unit Credit, Frozen Entry Age Normal, Attained Age, Frozen Attained Age, and Aggregate, etc). On average, 47 percent of the PENDAT public plans examined here used the Entry Age Normal cost method; 15 percent used the Projected Unit Credit approach; and the rest used other methods. 
${ }^{7}$ The analysis omits six PENDAT observations with stock or flow funding ratios greater than 500 percent; detailed evaluation of these cases suggests that such high funding ratios represent input error.

${ }^{8}$ See, for instance, Bahl and Jump (1974), Taylor (1986), Testin (1984, 1986), Testin and Snell (1989), and Turner and Beller (1989). Dulebohn (1995) evaluated 205 plans in 1988 and 1992 and concluded that public plans improved their funded status over time. More recent descriptive studies include Mitchell et al. (2000).

${ }^{9}$ Here we focus only on empirical studies on public pension plan funding. In the literature, the theoretical studies on the funding of public pension plans include Mumy (1978), Epple and Schipper (1981), and D’Arcy, Dulebohn and Oh (1999).

${ }^{10}$ Mitchell and Smith (1994) evaluated only the influence of stock funding ratio on flow funding ratio using a single survey year (1989). Their study found a positive, strong relationship between stock and flow funding ratio, supporting the hypothesis of behavioral persistence.

${ }^{11}$ Prior to 1996, the Governmental Accounting Standards Board (GASB) Statement No. 5 required public plans to report both the $\mathrm{AAL}$ and the $\mathrm{PBO}$, where $\mathrm{PBO}$ is a standardized measure calculated using projected benefit methods. From 1997 on, GASB Statement No.27 required plans to report only AAL measures. Mitchell and Hsin (1997) used the Projected Benefit Obligation (PBO) for PENDAT information prior to 1996. Results we report below are similar if we use PBO funding measures for the period 1990 to 1994 only (results available on request).

${ }^{12}$ For instance, Winkelvoss (1993) concluded that a 1 percent point increase in the discount rate reduces actuarial accrued liabilities by 16 percent, and a similar point is made by the US General Accounting Office (USGAO, 1993). 
${ }^{13}$ Following Winkelvoss (1993), pension actuarial liabilities as well as normal costs are measured under the AAL method altered by 4 percent for each $1 / 4$ of each percent change in the interest rate. To adjust liabilities, to a common discount rate, we first calculate $\mathrm{q}=$ (reported discount rate - standard discount rate) $/ 0.25$, where the standard discount rate is the mean discount rate for each year in our sample, and then multiply the reported AAL by $1.04^{\mathrm{q}}$. Hence if the plan's reported discount rate is larger than the standard discount rate, the adjusted AAL will be larger than the reported one, and vice versa. In unreported regressions, we also estimate two alternative models: one without adjusting the discount rate, and another with the discount rate decided simultaneously with the stock funding ratio. The estimated coefficients are similar in sign and significance to those reported below.

${ }^{14}$ It is possible that flow funding can also influence stock funding ratios; that is, stock funding may be larger when flow funding ratios have been higher. We experimented with this question by including lagged flow funding ratios in the stock funding regressions, but the coefficients were not statistically significant. In results not reported in detail here, we also re-estimate the model using 3SLS and 2SLS. Coefficients are similar in sign and magnitude, so in what follows, we simply present the pooled OLS results. As there are lagged variables in the equations, we tested the serial correlation in the error terms after doing the pooled OLS regression on the panel data as Wooldridge (2002) recommends. Since the error is a first-order autoregressive process, we use a robust variance matrix estimator.

${ }^{15}$ The education level of Board members may be positively related to their financial sophistication, but PENDAT contains no direct information on this point. We can test the hypothesis that teacher Board members are better educated than other members, by interacting 
Board composition with a teacher plan variable; however the interactions are not generally statistically significant (results available on request).

${ }^{16}$ For instance, North Carolina's governor suspended contributions to the state retirement system when faced with an impending budget shortfall in 2001 (Chaney, Copley, and Stone, 2002).

${ }^{17}$ Unemployment rates are drawn from the Bureau of Labor Statistics website at www.bls.gov. Indicators of budget carry-over are taken from Bohn and Inman (1996). Annual S\&P500 returns are derived from CRSP.

${ }^{18}$ Conclusions are similar if we limit the analysis only to those plans included in all years (results available on request).

${ }^{19}$ It is possible that there is some reverse causality here, which might arise if reports were issued only by the well-managed funds which also perform better. However, since $96 \%$ of the funds do issue reports, such censoring is likely to be relatively unimportant. 